\title{
Influence of dietary protein concentration on the oxidation of phenylalanine by the young pig
}

\author{
BY RONALD O. BALL AND HENRY S. BAYLEY* \\ Department of Nutrition, University of Guelph, Guelph, Ontario, Canada N1G 2WI
}

(Received 2 January 1986 - Accepted 15 January 1986)

\begin{abstract}
1. Piglets were weaned at $3 \mathrm{~d}$ of age and reared to $2.5 \mathrm{~kg}$ on a liquid diet in which the protein was supplied by dried skim milk and a mixture of free amino acids. The oxidation of $\mathrm{L}-\left[1-{ }^{14} \mathrm{C}\right]$ phenylalanine was measured as an indication of the partition of amino acids between retention and catabolism in pigs $(2.5 \mathrm{~kg})$ offered meals containing varied concentrations of crude protein (nitrogen $\times 6.25$ ).

2. The dietary protein concentration was varied either by increasing the inclusion of a mixture of free amino acids in a series of diets containing $100 \mathrm{~g}$ protein $/ \mathrm{kg}$ from skim milk, or by increasing the level of inclusion of the skim milk in a series of diets containing the equivalent of $100 \mathrm{~g}$ protein $/ \mathrm{kg}$ from the free amino acid mixture.

3. The oxidation of phenylalanine was minimized by dietary protein concentrations of 240 and $258 \mathrm{~g} / \mathrm{kg}$ for the diets containing increasing concentrations of free amino acids or skim milk respectively.

4. These results show that a mixture of free amino acids is used more effectively than intact protein for promoting retention of essential amino acids.

5. The recovery of radioactivity in expired carbon dioxide was inversely related to the recovery of radioactivity in liver tissue when the concentration of dietary crude protein was increased from deficient to adequate, demonstrating that the fractional oxidation of the indicator amino acid was inversely related to protein synthesis.
\end{abstract}

A review of the response of pigs to variation in the dietary protein concentration concluded that it was difficult to arrive at recommendations for the piglet of $1-5 \mathrm{~kg}$ when faced with very scarce and variable information (Agricultural Research Council, 1981). The variability in the reported values is largely due to the low growth rates and poor health status in piglets receiving diets in which cow's-milk products have been replaced by non-milk protein sources. The development of a semi-synthetic diet in which 0.6 of the crude protein (nitrogen $\times 6.25$ ) is supplied as a mixture of free amino acids (Ball et al. 1984) provided the opportunity to manipulate the dietary levels of amino acids to study the amino acid requirements of piglets growing similarly to piglets reared on the sow.

Cole (1979) discussed the protein requirement of growing pigs on the basis that they responded to increasing dietary protein concentration because of the increase in the supply of the first limiting amino acid. The oxidation of $\left[{ }^{14} \mathrm{C}\right]$ phenylalanine has been used to indicate the partition of dietary amino acids between retention and catabolism when the dietary concentration of individual amino acids was increased from deficient through adequate to excess (Kim et al. 1983 $\mathrm{b}$ ). Therefore the oxidation of $\left[{ }^{14} \mathrm{C}\right]$ phenylalanine with increasing dietary protein concentration, based on the response of the pig to the most limiting amino acid, should be useful for determining the dietary protein concentration required to maximize tissue deposition of the dietary amino acids. Such a technique would allow the short-term measurement of dietary protein requirement of animals following changes in weight, age, environmental or physiological status.

The study to be described examined the effect of varying dietary protein concentration on the oxidation of phenylalanine by piglets receiving meals containing either a fixed concentration of intact protein (from skim milk) with varying concentrations of free amino acids, or receiving diets containing a fixed concentration of free amino acids with varying concentrations of skim milk. 
Table 1. Details of diet*

\begin{tabular}{|c|c|c|c|}
\hline \multirow[b]{2}{*}{ Ingredients } & & \multicolumn{2}{|c|}{ Formulation $(\mathrm{g} / \mathrm{kg})$} \\
\hline & & Skim milk & Amino acid \\
\hline \multicolumn{2}{|l|}{ Dried skim milk $\dagger$} & 740 & 296 \\
\hline \multicolumn{2}{|l|}{ Glucoset } & 13 & 301 \\
\hline \multicolumn{2}{|l|}{ Maize oil } & 200 & 200 \\
\hline \multicolumn{2}{|l|}{ Minerals§ } & $44 \cdot 5$ & $44 \cdot 5$ \\
\hline \multicolumn{2}{|l|}{ Vitamins $\|$} & $2 \cdot 5$ & $2 \cdot 5$ \\
\hline \multicolumn{2}{|l|}{ Amino acid mixture } & 0 & 156 \\
\hline \multicolumn{4}{|c|}{ Composition of amino acid mixture $(\mathrm{g})$} \\
\hline Arginine & $5 \cdot 1$ & Cystine & $2 \cdot 2$ \\
\hline Histidine & $3 \cdot 8$ & Phenylalanine & $6 \cdot 4$ \\
\hline Isoleucine & $9 \cdot 9$ & Tyrosine & $5 \cdot 6$ \\
\hline Leucine & $14 \cdot 2$ & Threonine & $6 \cdot 0$ \\
\hline Lysine-hydrochloride & $12 \cdot 1$ & Tryptophan & $1 \cdot 7$ \\
\hline Methionine & 3.4 & Valine & $9 \cdot 5$ \\
\hline \multirow[t]{2}{*}{ Non-essential amino acids** } & $76 \cdot 1$ & & \\
\hline & & Total & 156 \\
\hline
\end{tabular}

* Mixed with water $(1: 4, w / v)$, homogenized and cooled before feeding.

$\uparrow$ Gay Lea; Guelph, Ontario, Canada.

$\ddagger$ Cerelose; Corn Products, CPC International Inc; Englewood Cliffs, New Jersey, USA.

$\S$ As $\mathrm{mg} / \mathrm{kg}$ diet: $\mathrm{CaH}_{4}\left(\mathrm{PO}_{4}\right)_{2} \cdot \mathrm{H}_{2} \mathrm{O} 24000, \quad \mathrm{CaCO}_{3} 10500, \quad \mathrm{NaCl}(0 \cdot 15 \mathrm{~g} \mathrm{I} / \mathrm{kg}) 3000, \mathrm{~K}_{2} \mathrm{CO}_{3} 1770$, $\mathrm{MgSO}_{4} .7 \mathrm{H}_{2} \mathrm{O} 4060, \mathrm{FeSO}_{4} .7 \mathrm{H}_{2} \mathrm{O} 625, \mathrm{ZnSO}_{4} .7 \mathrm{H}_{2} \mathrm{O} 435, \mathrm{MnSO}_{4} . \mathrm{H}_{2} \mathrm{O} 61 \cdot 5, \mathrm{CuSO}_{4} .5 \mathrm{H}_{2} \mathrm{O} 23 \cdot 6, \mathrm{NaSeO}_{3} 0.22$.

$\|$ As $\mathrm{mg} / \mathrm{kg}$ diet : niacin 44 , calcium D-pantothenate $28 \cdot 4$, riboflavin 6 , pyridoxine $3 \cdot 6$, thiamin hydrochloride 3 , folic acid 2, D-biotin $0 \cdot 2, \alpha$-tocopheryl acetate 15 , menadione 2, retinyl acetate $0 \cdot 8$, cholecalciferol $0 \cdot 011$, cyanocobalamin $0 \cdot 044$, choline chloride 2000.

I United States Biochemical Corporation, Cleveland, Ohio, USA.

** Included $(\mathrm{g} / \mathrm{kg}$ diet $)$ : alanine $8 \cdot 3$, aspartic acid $5 \cdot 3$, asparagine $5 \cdot 3$, glutamic acid $16 \cdot 3$, glutamine $16 \cdot 3$, glycine $16 \cdot 4$, proline $4 \cdot 1$, serine $4 \cdot 1$.

\section{EXPERIMENTAL}

\section{Animals and management}

Yorkshire-type male piglets from the University of Guelph's minimal-disease herd were weaned at 3-4 d of age and transferred to the laboratory where they were housed in individual wire cages. The mean weight of the sixty-three piglets was $1.75 \mathrm{~kg}$ at weaning. The temperature at piglet level was maintained at $32^{\circ}$ utilizing supplementary heat lamps. The laboratory was lighted from 08.00 to 22.00 hours.

\section{Diet composition}

The two diets used during the growing period contained either skim milk or a mixture of skim milk and amino acids (Table 1). The piglets received the skim milk diet for $2 \mathrm{~d}$ after weaning and the amino acid diet thereafter. The amino acid diet contained $240 \mathrm{~g}$ crude protein $/ \mathrm{kg}$ with 0.6 of the dietary $\mathrm{N}$ being provided by a mixture of free amino acids: the essential amino acids in a pattern similar to that of skim milk, and the non-essentials based upon those of Rogers \& Harper (1965). The diets were offered in liquid form $(1: 4, w / v)$ as six meals between 08.00 and 21.00 hours.

In Expt 1, the dietary protein concentration was increased by increasing the level of free amino acids in the diet. Diets A and B (Table 2) were blended to provide protein concentrations of $120,160,200,240,260,280$ and $320 \mathrm{~g} / \mathrm{kg}$ diet. Diet A contained a total of $100 \mathrm{~g}$ crude protein $/ \mathrm{kg}$ as dried skim milk while diet $\mathrm{B}$ contained $320 \mathrm{~g}$ crude protein $/ \mathrm{kg}$ : 
Table 2. Diets blended to provide graded levels of dietary protein with either varied levels of amino acids (Expt 1) or varied levels of skim milk (Expt 2)

\begin{tabular}{|c|c|c|c|c|}
\hline \multirow[b]{3}{*}{ Ingredient } & \multicolumn{4}{|c|}{ Formulation $(\mathrm{g} / \mathrm{kg})$} \\
\hline & \multicolumn{2}{|c|}{ Expt 1} & \multicolumn{2}{|c|}{ Expt 2} \\
\hline & Diet A & Diet B & Diet C & Diet $\mathbf{D}$ \\
\hline Skim milk* & 296 & 296 & 179 & 537 \\
\hline Glucose* & 457 & $204 \cdot 1$ & $422 \cdot 25$ & $64 \cdot 25$ \\
\hline Maize oil & 200 & 200 & 200 & 200 \\
\hline Minerals* & 44.5 & 44.5 & 44.5 & $44 \cdot 5$ \\
\hline Amino acid mix ${ }^{\dagger}$ & 0 & 244.5 & 111.75 & $111 \cdot 75$ \\
\hline Total & $991.6 \ddagger$ & $991.6 \ddagger$ & 9608 & 960 s \\
\hline Crude protein (nitrogen $\times 6.25$ ) & 100 & 320 & 160 & 280 \\
\hline
\end{tabular}

* See Table 1.

$\dagger$ As in Table 1 except phenylalanine and tyrosine were removed. In diets C and D these amino acids were replaced by an equal weight of glucose.

+ Phenylalanine $(4.5 \mathrm{~g} / \mathrm{kg})$ and tyrosine $(3.9 \mathrm{~g} / \mathrm{kg})$ were added during blending of the meals to bring the diet total to $1000 \mathrm{~g}$.

$\S$ Phenylalanine and tyrosine added to total 8.8 and $8.5 \mathrm{~g} / \mathrm{kg}$ diet respectively. Glucose was added to bring the total to $1000 \mathrm{~g}$.

$100 \mathrm{~g}$ as dried skim milk and $220 \mathrm{~g}$ protein equivalent as a mixture of free amino acids. This allowed the concentration of intact protein to be maintained at $100 \mathrm{~g} / \mathrm{kg}$ in all the diets.

The concentration of total and free phenylalanine was maintained constant in all the diets to avoid a variable dilution of the $\left[{ }^{14} \mathrm{C}\right]$ phenylalanine with dietary phenylalanine. Phenylalanine and tyrosine were not included in diet $\mathbf{B}$, but were added at constant levels of 4.5 and $3.9 \mathrm{~g} / \mathrm{kg}$ respectively, during the mixing of the individual experimental diets. The total concentrations of phenylalanine and tyrosine in all the diets were equivalent to the concentrations found in the diet containing $200 \mathrm{~g}$ crude protein $/ \mathrm{kg}: 8.8$ and $8.5 \mathrm{~g} / \mathrm{kg}$ respectively. These concentrations were chosen because they exceeded the requirements for phenylalanine $(7.3 \mathrm{~g} / \mathrm{kg})$ and phenylalanine plus tyrosine $(9.0 \mathrm{~g} / \mathrm{kg})$ determined by oxidation by Kim et al. (1983 b) and Bayley et al. (1981) respectively for piglets receiving similar diets. This ensured that the changes in oxidation with changes in dietary protein concentration were not due to a limitation in the concentration of phenylalanine.

In Expt 2 the dietary protein concentration was increased by increasing the concentration of skim milk in the diet. Diets $\mathrm{C}$ and $\mathrm{D}$ were blended to provide protein concentrations of $160,200,240,260$ and $280 \mathrm{~g} / \mathrm{kg}$. Both diets $C$ and D contained $100 \mathrm{~g}$ protein equivalent from the mixture of free amino acids, with dried skim milk supplying 60 and $180 \mathrm{~g} / \mathrm{kg}$ respectively. All the diets in this experiment contained the equivalent of $100 \mathrm{~g}$ protein $/ \mathrm{kg}$ from free amino acids. The concentrations of phenylalanine and tyrosine provided by the skim milk increased with increasing dietary protein. Free phenylalanine and tyrosine were omitted from diets $\mathrm{C}$ and $\mathrm{D}$ but were added to each of the experimental diets to bring the total to 8.8 and $8.5 \mathrm{~g} / \mathrm{kg}$ respectively, as in Expt 1 . Addition of glucose balanced the changes in phenylalanine and tyrosine supplementation.

In Expt 2 the highest concentration of protein used was $280 \mathrm{~g} / \mathrm{kg}$ because, at higher concentrations, the phenylalanine and tyrosine provided by the skim milk would have exceeded the concentrations used in Expt 1. The constant phenylalanine and tyrosine concentration allowed comparison of the oxidation levels between Expts 1 and 2. 


\section{Recovery of labelled carbon dioxide}

When the piglets weighed approximately $2.5 \mathrm{~kg}$ they were fasted overnight $(14 \mathrm{~h})$, then offered two meals, each consisting of $100 \mathrm{ml}$ of an experimental diet and $10 \mu \mathrm{Ci} \mathrm{L}-$ $\left[1-{ }^{14} \mathrm{C}\right]$ phenylalanine, 4 and $2 \mathrm{~h}$ before a $60 \mathrm{~min}$ collection period. The feeding regimen and collection protocol were chosen to make the release of ${ }^{14} \mathrm{CO}_{2}$ most sensitive to changes in the adequacy of the dietary $\mathrm{N}$ (Ball \& Bayley, 1985). The feeding regimen was also shown by Kim et al. $(1983 b)$ to result in no change in the specific activity of liver free-phenylalanine during the $\mathrm{CO}_{2}$ collection period.

The piglet was placed in a Plexiglass chamber $(400 \times 400 \times 600 \mathrm{~mm}) 20 \mathrm{~min}$ before the collection began to allow the $\mathrm{CO}_{2}$ to equilibrate in the ventilating air-stream. The air flow-rate was 14 litres/min and the expired ${ }^{14} \mathrm{CO}_{2}$ was collected by passing the air over a condenser to remove water vapour, then through three gas-washing bottles containing $\mathrm{CO}_{2}$ absorber (ethanolamine-ethylene glycol monomethylether; $1: 2, \mathrm{v} / \mathrm{v}$ ). Radioactivity of the $\mathrm{CO}_{2}$ was determined by adding a portion of the absorbing mixture to $15 \mathrm{ml}$ ACS (Amersham Corp., Arlington Heights, Illinois), dark-adapting for $4 \mathrm{~h}$ and counting in a liquid scintillation spectrometer (Delta 300; Searle Analytical, Toronto). The count rates were corrected for background and for counting efficiency using the external channels ratio method. The mean background and counting efficiency were 96 counts/min and $86 \%$ respectively.

\section{Analysis of liver radioactivity}

The livers were removed from all the piglets, in both experiments $15 \mathrm{~min}$ after the end of the $\mathrm{CO}_{2}$ collection interval ( $3.25 \mathrm{~h}$ following the second meal). The livers were drained of blood, blotted dry, weighed and frozen until analysed. Three $50 \mathrm{mg}$ samples from each liver were solubilized by digesting at $55^{\circ}$ for $18 \mathrm{~h}$ in $1.5 \mathrm{ml} \mathrm{NCS} \mathrm{(Amersham} \mathrm{Corp.).} \mathrm{The} \mathrm{samples}$ were cooled to room temperature and neutralized with $0.045 \mathrm{ml}$ glacial acetic acid. Samples were shaken with $15 \mathrm{ml}$ Econofluor (New England Nuclear, Montreal) and dark-adapted for at least $48 \mathrm{~h}$. Radioactivity was determined by liquid scintillation counting (Beckman Model no. LS 7800; Beckman Instruments Inc., Irvine, California) in the ${ }^{14} \mathrm{C}$ channel with the counting error delimiter set at $1 \%$. The mean background and counting efficiency were 96 counts $/$ min and $91 \%$ respectively. The distribution of radioactivity between protein and non-protein fractions was determined in a subset of liver samples from Expt 1 by homogenizing the samples in $5 \mathrm{ml}$ trichloroacetic acid (TCA) and separating the supernatant fraction by centrifugation. The supernatant fraction was shaken with diethyl ether to remove the TCA and a sample taken for determination of radioactivity. The precipitated protein was resuspended, washed three times with TCA, two times with diethyl ether and then solubilized as described above.

\section{Statistical analysis}

The ${ }^{14} \mathrm{CO}_{2}$ evolution results of Expts 1 and 2 were analysed to determine the break point by the two-phase linear-regression crossover model previously described (Kim et al. 1983b). The influence of increasing dietary protein concentration on liver radioactivity was examined by linear-regression analysis (Seber, 1977).

\section{RESULTS}

Fig. 1 shows that increasing the dietary protein concentration from 120 to $240 \mathrm{~g} / \mathrm{kg}$ by adding free amino acids produced a linear reduction in the catabolism of $\left[{ }^{14} \mathrm{C}\right]$ phenylalanine. Further increases up to $320 \mathrm{~g} / \mathrm{kg}$ had no effect on phenylalanine oxidation. Regression analysis of the results showed that phenylalanine oxidation was minimized at $240 \mathrm{~g}$ protein $/ \mathrm{kg}(95 \%$ confidence interval of $239-241 \mathrm{~g} / \mathrm{kg})$. 


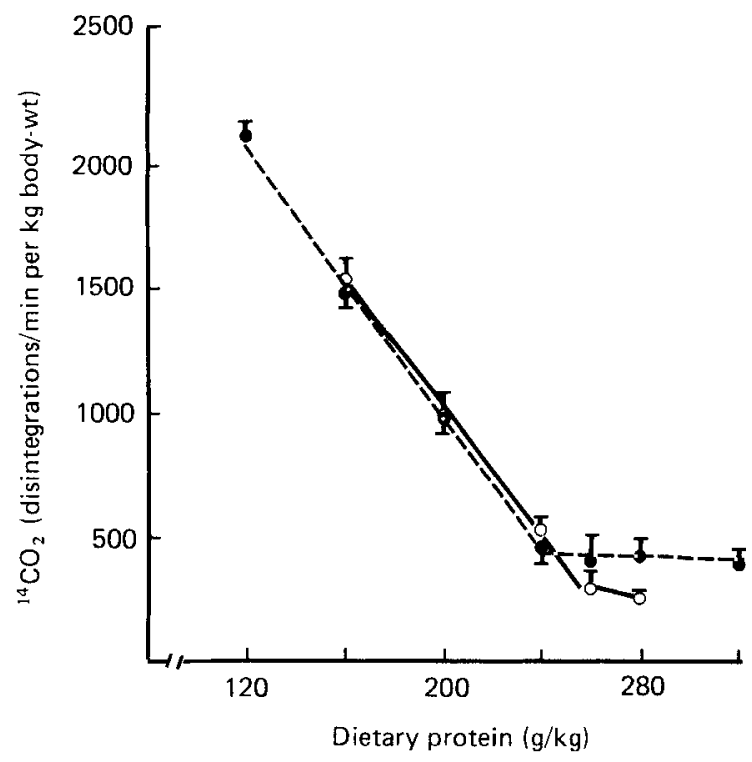

Fig. 1. Influence of dietary protein level on the oxidation of phenylalanine. Means, with their standard errors represented by vertical bars, for the radioactivity recovered as carbon dioxide in $\mathrm{l} h$ from pigs which had received two meals after an overnight fast. Each meal contained $10 \mu \mathrm{Ci} \mathrm{L}-\left[1-{ }^{14} \mathrm{C}\right] p h e n y l a l a n i n e$, $8.8 \mathrm{~g}$ phenylalanine $/ \mathrm{kg}, 8.5 \mathrm{~g}$ tyrosine $/ \mathrm{kg}$ and graded levels of protein. Protein levels were achieved by maintaining skim milk protein constant at $100 \mathrm{~g} / \mathrm{kg}$ and increasing free amino acid concentration $(0----)(n 40)$ or by maintaining free amino acid protein constant at $100 \mathrm{~g} / \mathrm{kg}$ and increasing skim milk concentration $(\mathrm{O}-\mathrm{O})(n 23)$. Lines were fitted by regression analysis. For protein varied by free amino acids, the means (with SE) for weight, age and growth rate of the piglets were $2.48(0.02) \mathrm{kg}$, $12.0(0.31) \mathrm{d}$ and $125(4.9) \mathrm{g} / \mathrm{d}$ respectively. For protein varied by skim milk, the means (with $\mathrm{SE}$ ) for weight, age and growth rate of the piglets were $2.45(0.04) \mathrm{kg}, 12.9(0.39) \mathrm{d}$ and $131(4.9) \mathrm{g} / \mathrm{d}$ respectively.

Increasing the dietary protein concentration in Expt 2 from 160 to $280 \mathrm{~g} / \mathrm{kg}$ by adding dried skim milk reduced phenylalanine catabolism, oxidation being minimized at $258 \mathrm{~g}$ protein $/ \mathrm{kg}$ diet $(95 \%$ confidence interval of $256-260 \mathrm{~g} / \mathrm{kg}$ ) (Fig. 1).

The effect of varying protein concentration by addition of either skim milk or free amino acids on the incorporation of $\left[{ }^{14} \mathrm{C}\right]$ phenylalanine into liver tissue is shown in Fig. 2. In both experiments the recovery of $\left[{ }^{14} \mathrm{C}\right]$ phenylalanine in liver tissue was highest at the concentration of dietary protein which minimized phenylalanine oxidation. There were significant linear increases in recovery of radioactivity in the liver with increasing dietary protein up to these concentrations. Further increases in dietary protein resulted in no significant increase in the radioactivity recovered in the livers. These results support the hypothesis that the oxidation of phenylalanine is representative of the partition of amino acids between oxidation and protein synthesis in the liver.

The proportions of the radioactivity recovered in the protein fraction of the livers for piglets in Expt 1 receiving diets containing either 120, 240 or $320 \mathrm{~g}$ crude protein $/ \mathrm{kg}$ were $97.8,98.1$ and 97.5 respectively $(n 9$, SEM 0.5$)$ showing that the dietary protein concentration did not influence the distribution of label between the protein and nonprotein fractions of the liver.

\section{DISCUSSION}

The oxidation of $\left[{ }^{14} \mathrm{C}\right]$ phenylalanine responds to increases in the dietary concentrations of single amino acids from deficient to adequate (Kim \& Bayley, 1983; Kim et al. 1983a, $b$; 


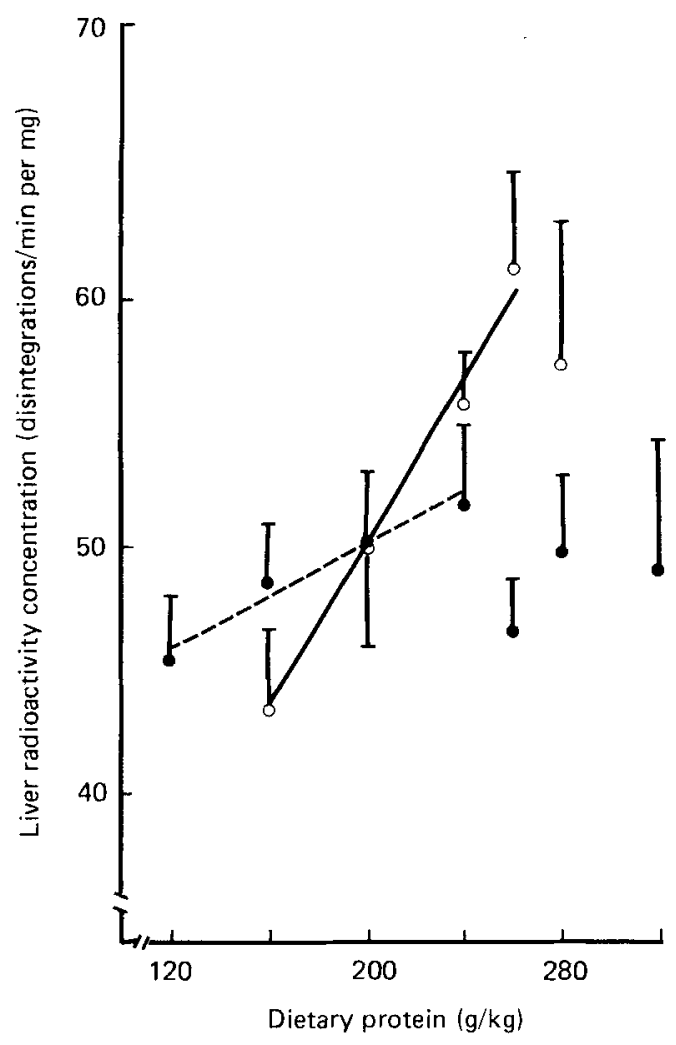

Fig. 2. Influence of dietary protein level on the recovery of radioactivity in liver samples. Means, with their standard errors represented by vertical bars, for the radioactivity recovered in $100 \mathrm{mg}$ liver tissue in pigs which had received two meals after an overnight fast. Each meal contained $10 \mu \mathrm{Ci} L-[1$ ${ }^{14} \mathrm{C}$ phenylalanine, $8.8 \mathrm{~g}$ phenylalanine $/ \mathrm{kg}, 8.5 \mathrm{~g}$ tyrosine $/ \mathrm{kg}$ and graded levels of protein. Protein levels were achieved by maintaining skim milk protein constant at $100 \mathrm{~g} / \mathrm{kg}$ and increasing free amino acid concentration ( $----O)(n 40)$ or by maintaining free amino acid protein constant at $100 \mathrm{~g} / \mathrm{kg}$ and increasing skim milk concentration $(\mathrm{O}-\mathrm{O})(n 23)$. Lines were fitted by regression analysis for the protein levels increasing from deficient to adequate. The equations for the two lines are: (1) increasing free amino acid $(120-240 \mathrm{~g}$ protein $/ \mathrm{kg})$, disintegrations $/ \mathrm{min}$ per $100 \mathrm{mg}=3976.67+(52.93 \times$ protein level), $r^{2} 0.884, \mathrm{SE}$ of the estimate $122 \cdot 32 ;(2)$ increasing skim milk $(160-260 \mathrm{~g}$ protein $/ \mathrm{kg})$, disintegrations $/ \mathrm{min}$ per $100 \mathrm{mg}=1942.56+(152.38 \times$ protein level $), r^{2} 0.853$, sE of the estimate 98.57 .

Ball \& Bayley, 1984). These results extend the application of the oxidation of an indicator amino acid to the determination of the response of piglets to increasing dietary protein concentration, providing a clear conclusion as to the optimum protein level in the diet by making observations on piglets at a single weight, growing at a uniform rate. The changes in phenylalanine oxidation with increasing protein concentration show that fractional phenylalanine oxidation may be responsive to changes in protein retention.

In these experiments all amino acids except phenylalanine were being provided in a constant ratio. The rate of whole-body protein deposition may have been responding to the increasing supply of the most limiting amino acid. Since phenylalanine was maintained at the same dietary concentration at all concentrations of protein, the relative excess of phenylalanine would decrease with increasing dietary concentration of the limiting amino acid, providing phenylalanine for oxidation in inverse proportion to the amount taken up for protein synthesis. This hypothesis is supported by the increasing incorporation of 
$\left[{ }^{19} \mathrm{C}\right]$ phenylalanine into liver tissue as dietary protein concentration increased from deficient up to the adequate level (Fig. 2). The similarity in the proportions of radioactivity recovered in the protein-bound fraction of the liver indicates that the observed changes in fractional phenylalanine oxidation and incorporation into liver tissue are not due to changes in the distribution of $\left[{ }^{14} \mathrm{C}\right]$ phenylalanine between the protein-bound and non-protein-bound amino acid pool.

In a study involving dietary protein concentrations and amino acid oxidation (Motil et al. 1981), the dietary concentration of the amino acid whose oxidation was being measured, was allowed to vary according to its concentration in the protein. Motil et al. (1981) measured specific activities of leucine and lysine in the plasma and by assuming that this was indicative of the specific activities of the tissues at the site of protein synthesis they concluded that the oxidations of leucine and lysine observed at three levels of dietary protein were related to the total $\mathrm{N}$ and amino acid requirements of the individual. Their suggestion that amino acid oxidation is related to protein requirements is supported by the results of the current experiments. However, in these experiments the problems of variable dilution of the labelled free amino acid with unlabelled dietary amino acid were eliminated as a complicating factor by maintaining a constant concentration of the indicator amino acid in all the diets. This may have contributed to the observation of a clear breakpoint in the relation between dietary protein concentration and amino acid oxidation.

A factor which may complicate the interpretation of requirements from amino acid oxidation experiments is the allowance of an adaptation period. Adaptation to a diet containing an inadequate protein concentration results in decreases in protein synthesis, protein breakdown and amino acid oxidation relative to an adequate protein concentration, whereas adaptation to excess dietary protein increases these activities. The relative and absolute levels of these activities differ at inadequate, adequate and excess levels of intake (Neale \& Waterlow, 1974; Waterlow et al. 1978; Reeds \& Fuller, 1983). Therefore, the amino acid oxidation response to dietary protein concentration may be easier to interpret if adaptation to different dietary concentrations is eliminated. In these experiments all the animals received a diet containing adequate dietary protein until the day of the experiment.

The estimates of protein requirement obtained in these experiments by phenylalanine oxidation, of 240 and $258 \mathrm{~g} / \mathrm{kg}$, are similar to estimates obtained from growth studies with piglets fed on milk-based diets: $240 \mathrm{~g} / \mathrm{kg}$ (Lloyd \& Crampton, 1961), $250 \mathrm{~g} / \mathrm{kg}$ (Manners \& McCrea, 1962), $240 \mathrm{~g} / \mathrm{kg}$ (Braude et al. 1976) and $270 \mathrm{~g} / \mathrm{kg}$ (Braude et al. 1977).

The higher estimate of dietary protein requirement in Expt 2 may reflect the increasing proportions of the amino acids being supplied from intact protein. The protein levels of 240 and $258 \mathrm{~g} / \mathrm{kg}$ diet estimated as being required in Expts 1 and 2 respectively, were provided by $100 \mathrm{~g}$ from skim milk and $140 \mathrm{~g}$ from the amino acid mixture in Expt 1, and as $158 \mathrm{~g}$ from skim milk and $100 \mathrm{~g}$ from the amino acid mixture in Expt 2. If the amino acids were completely available from the amino acid mixture, but only fractionally available from the skim milk this could account for the higher estimate of requirement for the diet with the higher level of skim milk protein (Expt 2), but for this explanation to account for all the difference, the biological availability of the limiting amino acid in the skim milk would be only $0 \cdot 7$, much lower than the digestibility of the protein in skim milk.

There are other reports of a higher dietary protein requirement when intact protein rather than free amino acids are consumed, for the growing pig (Robbins \& Baker, 1977), chick (Baker, 1977) and rat (Rogers \& Harper, 1965).

The estimates of requirement from Expts 1 and 2 varied between 240 and $258 \mathrm{~g} / \mathrm{kg}$, with intact protein:amino acid values of $1: 1.4$ and 1:0.625 respectively. Muller \& Kirchgessner (1974), using diets containing casein and skim milk, estimated the protein requirement of pigs of $4-11 \mathrm{~kg}$ to be either 240,260 or $340 \mathrm{~g} / \mathrm{kg}$ using gain, efficiency of $\mathrm{N}$ retention or 
maximum $\mathrm{N}$ retention respectively, as indices of response. Similarly, Newport (1979) determined the protein requirement in pigs receiving diets of skim milk plus whey, between 2 and $28 \mathrm{~d}$ of age, to be 240 and $270 \mathrm{~g} / \mathrm{kg}$ by $\mathrm{N}$ retention and gain respectively. The values of McCracken et al. (1980) for piglets of 8-16 d of age, indicated the dietary protein requirement to be $285 \mathrm{~g} / \mathrm{kg}$ by gain and $201 \mathrm{~g} / \mathrm{kg}$ by efficiency of $\mathrm{N}$ retention. Obviously the use of different response criteria will give differing estimates of protein requirement but the results of the present study using amino acid oxidation is supported by these other experiments.

The results of these studies show that the indicator amino acid oxidation technique can be used to estimate dietary protein requirements. The inverse relation between the recovery of radioactivity in liver tissue and recovery of radioactivity in $\mathrm{CO}_{2}$, when dietary protein was increased from deficient to adequate, demonstrated that fractional oxidation of the indicator amino acid is inversely related to its retention in liver protein.

This work was supported by the Natural Sciences and Engineering Research Council of Canada and the Ontario Ministry of Agriculture and Food.

\section{REFERENCES}

Agricultural Research Council (1981). The Nutrient Requirements of Pigs. Slough: Commonwealth Agricultural Bureaux

Baker, D. H. (1977). In Advances in Nutritional Research, vol. 1, pp. 299-335 [H. H. Draper, editor]. New York: Plenum Publishing Corporation.

Ball, R. O. \& Bayley, H. S. (1984). Journal of Nutrition 114, 1741-1746.

Ball, R. O. \& Bayley, H. S. (1985). Canadian Journal of Physiology and Pharmacology 63, 1170-1174.

Ball, R. O., Kim, K. I. \& Bayley, H. S. (1984). Canadian Journal of Animal Science 64, 1019-1022.

Bayley, H. S., Kim, K. I. \& Sorfleet, J. L. (1981). Federation Proceedings 40, 3513.

Braude, R., Keal, H. D. \& Newport, M. J. (1976). British Journal of Nutrition 35, 253-258.

Braude, R., Keal, H. D. \& Newport, M. J. (1977). British Journal of Nutrition 37, 187-194.

Cole, D. J. A. (1979). In Recent Advances in Animal Nutrition-1978, pp. 59-72 [W. Haresign and D. Lewis, editors]. London: Butterworths.

Kim, K. I. \& Bayley, H. S. (1983). British Journal of Nutrition 50, 383-390.

Kim, K. I., Elliot, J. I. \& Bayley, H. S. (1983a). British Journal of Nutrition 50, 391-399.

Kim, K. I., McMillan, I. \& Bayley, H. S. (1983b). British Journal of Nutrition 50, 369-382.

Lloyd, L. E. \& Crampton, E. W. (1961). Journal of Animal Science 20, 172-175.

McCracken, K. J., Eddie, S. M. \& Stevenson, W. G. (1980). British Journal of Nutrition 43, 289-304.

Manners, M. J. \& McCrea, M. R. (1962). British Journal of Nutrition 16, 475-482.

Motil, K. J., Matthews, D. E., Bier, D. M., Burke, J. F., Munro, H. N. \& Young, V. R. (1981). American Journal of Physiology 240, E712-E721.

Muller, von H. L. \& Kirchgessner, M. (1974). Zeitschrif für Tierphysiologie, Tierernahrung und Futtermittelkunde 33, $98-107$

Neale, R. J. \& Waterlow, J. C. (1974). British Journal of Nutrition 32, 11-25.

Newport, M. J. (1979). British Journal of Nutrition 41, 95-101.

Reeds, P. J. \& Fuller, M. F. (1983). Proceedings of the Nutrition Society 42, 463-471.

Robbins, K. R. \& Baker, D. H. (1977). Journal of Animal Science 45, 113-118.

Rogers, Q. R. \& Harper, A. E. (1965). Journal of Nutrition 87, 267-273.

Seber, G. A. F. (1977). Linear Regression Analysis. New York: John Wiley.

Waterlow, J. C., Garlick, P. J. \& Millward, D. J. (1978). Protein Turnover in Mammalian Tissues and in the Whole Body, pp. 698-715. Amsterdam: North-Holland Publishing Co. 